University of Nebraska - Lincoln

DigitalCommons@University of Nebraska - Lincoln

West Central Research and Extension Center, North Platte

Agricultural Research Division of IANR

2012

Ecosystem Services: The Significance of Contributions by

Invasive Plant Species

Stephen L. Young

University of Nebraska - Lincoln, steve.young@usu.edu

Follow this and additional works at: https://digitalcommons.unl.edu/westcentresext

Part of the Agriculture Commons

Young, Stephen L., "Ecosystem Services: The Significance of Contributions by Invasive Plant Species" (2012). West Central Research and Extension Center, North Platte. 24.

https://digitalcommons.unl.edu/westcentresext/24

This Article is brought to you for free and open access by the Agricultural Research Division of IANR at DigitalCommons@University of Nebraska - Lincoln. It has been accepted for inclusion in West Central Research and Extension Center, North Platte by an authorized administrator of DigitalCommons@University of Nebraska - Lincoln. 


\title{
Ecosystem Services: \\ The Significance of Contributions by Invasive Plant Species
}

\author{
Stephen L. Young \\ Department of Agronomy and Horticulture \\ West Central Research \& Extension Center \\ University of Nebraska-Lincoln \\ syoung4@unl.edu
}

Across vast expanses of rangelands, prairies, woodlands, and forests and throughout many wetlands and riparian corridors, invasive plant species have established and continue to threaten ecosystems. The number of invasive plant species on record in the United States is greater than 4,000 (Westbrooks 2004). The harm done by the establishment of invasive plant species includes reduced flow in waterways, disrupted fire regimes, and the loss of biodiversity in many natural areas. In the United States, it has been estimated that the cost for controlling invasive plant species is in excess of $\$ 120$ billion per year (Pejchar and Mooney 2009).

Ecosystem services are the inherent and tangible provisions supplied by and for natural systems that have direct benefits to humans (MEA 2005). The value of ecosystem services include: direct consumptive use values such as food, fiber, fuel, and pharmaceuticals; indirect use values such as nutrient cycles, disease resistance, or resilience to disturbances; direct nonconsumptive use values such as waste decomposition and air purification; and pure existence use values such as educational value, cultural importance, or aesthetic beauty. The means by which ecosystems provide these values go beyond simple primary productivity to include the maintenance of stable food webs and soil fertility, structural components such as soil and community composition, and biodiversity itself, which all can be affected by invasive plant species.

In quantifying ecosystem services, two objectives of the U.S. Environmental Protection Agency (USEPA 2007) stand out in relation to invasive plant species: (1) identify knowledge gaps in the processes underlying ecosystem services and (2) evaluate benefits of ecosystem services and trade-offs among management actions that affect these services. Although the number of hectares of invasive plant species continues to increase, in some cases rapidly (Duncan et al. 2004), information on their contribution to ecosystem services is severely lacking. Once the value of ecosystem services is determined, the value of managing invasive plant species can be fully realized, and better decisions can be made regarding the implementation of policies.

It is widely recognized that invasive plant species can establish in diverse environments, and with the increase in human mobility, they are no longer restricted to isolated pockets in remote parts of the world. Less emphasis is given to the fact that invasive plant species contribute to ecosystem services similar to those of other plant types, including native or nonnative desirable species. The significance of their contribution(s) is largely dependent on plant community composition and environmental conditions, which can change rapidly in a short period. For example, cheatgrass (Bromus tectorum L.) in rangelands, purple loosestrife (Lythrum salicaria L.) in wetlands, and tamarisk (Tamarix spp.) in riparian areas were introduced into the United States before the 19th century, yet their effects on economies and environments have only been felt more recently (Duncan et al. 2004).

Invasive plant species' contribution to ecosystem services is primarily viewed as negative because of their ability to out-compete native plant species and alter entire ecosystems, although in a few cases, services are enhanced (see Hershner and Havens 2008). In many states, laws have been established that enforce the removal of state and federal noxious plants and other invasive plants with monetary fines and penalties for noncompliance. By no means does this special feature or the symposium related to it advocated an alternative view. The main focus is to acknowledge existing invasive plant populations, determine their contributions to ecosystems, and better understand the entirety of the invasive plant species situation in the United States and around the world. 
With these concepts in mind, a symposium was organized to investigate the area of invasive plant species and ecosystem services and further our understanding of the contributions that invasive plants are making to ecosystem services, which, to date, has received limited attention.

The following symposium articles address three important areas of assessing the effects of invasive plant species on ecosystem services. Karie Decker et al., in "Landuse, landscapes, and biological invasions," introduce the concept of resilience in natural systems and use an analysis of the nonnative plants and land use types in Nebraska to emphasize the importance of predicting and quantifying changes in ecological structure, process, function, and ultimately services. Jeff Corbin and Carla D'Antonio, in "Gone but not forgotten? Invasive plants' legacies on community and ecosystem properties," examine the extent to which invasive species' effects on biodiversity, soil properties, and nutrient dynamics may persist after removal or death of the species. Valerie Eviner et al., in "Measuring the effects of invasive plants on ecosystem services: challenges and prospects," highlight current conceptual developments to better predict and manage the effects on the ecosystem of invasive plant species. The use of new methods and technologies to identify and quantify invasive plant species and ecosystem services will help in determining how to place a more accurate value on these systems for improved management and conservation.
Acknowledgments - The author extends his gratitude to the Soil and Water Conservation Society for providing the venue, the North Central Regional Center for Rural Development for partially funding "Ecosystem Services - The Significance of Contributions by Invasive Plant Species," and the five speakers: Craig Allen, Jeff Corbin, Valerie Eviner, Colin Brooks, and Chris Dionigi. Without the contributions from these organizations and individuals, the symposium would not have been possible.

\section{Literature Cited}

Duncan, C. A., J. J. Jachetta, M. L. Brown, et al. 2004. Assessing the economic, environmental, and societal losses from invasive plants on rangeland and wildlands. Weed Technol. 18:1411-1416

Hershner, C. and K. J. Havens. 2008. Managing invasive aquatic plants in a changing system: strategic consideration of ecosystem services. Conserv. Biol. 22:544-550

[MEA] Millennium Ecosystem Assessment. 2005. Ecosystems and Human Well Being: Synthesis. Washington, DC: Island Press. 155 p.

Pejchar, L. and H. A. Mooney. 2009. Invasive species, ecosystem services and human well-being. Trends Ecol. Evol. 24:497-504

[USEPA] U.S. Environmental Protection Agency. 2007. Willamette Ecosystem Services Project. Washington, DC: U.S. Environmental Protection Agency Rep. 600 R-07 057. 5 p.

Westbrooks, R. G. 2004. New approaches for early detection and rapid response to invasive plants in the United States. Weed Technol. 18:1468-1471 